\title{
Secondary Tumor Arising in a Nevus Sebaceous
}

\author{
Biljana JEREMIĆ GAJINOV1, 2, Sonja PRĆIĆ1, 3, Milana IVKOV SIMIĆ1, 2, Nada VUČKOVIĆ ${ }^{1,4}$, \\ Milan MATIĆ1, 2, Zoran GOLUŠIN¹, 2, Ljuba VUJANOVIĆ1, 2 \\ ${ }^{1}$ Faculty of Medicine, University of Novi Sad, Novi Sad, Serbia \\ ${ }^{2}$ Clinic of Dermatovenereology Diseases, Clinical Center of Vojvodina, Novi Sad, Serbia \\ ${ }^{3}$ Pediatric Clinic, Institute for Child and Youth Health Care of Vojvodina, Novi Sad, Serbia \\ ${ }^{4}$ Center for Pathology and Histology, Clinical Center of Vojvodina, Novi Sad, Serbia \\ Correspondence: Biljana Jeremić Gajinov, E-mail: biljana.jeremic@mf.uns.ac.rs \\ UDC 616.594-006-091.8
}

\begin{abstract}
Introduction. Nevus sebaceous is a rare congenital hamartoma, composed of epidermis, sebaceous glands, sweat glands and hair follicles. It is possible to develop secondary tumors in the area of nevus sebaceous during the lifetime, most often after puberty. Secondary lesions are most often benign, while malignant lesions may occur but significantly less frequently. Case report. We present the case of a 21-year-old patient who came for an examination due to the appearance of a nodule in the area of a yellowish lesion on the head. The yellowish lesion was present since birth, and the nodule appeared about a year before. The dermoscopic examination of the lesion was nonspecific. The final diagnosis of eccrine poroma as a secondary lesion in nevus sebaceous was made by pathohistological analysis. Conclusion. Every secondary tumor in nevus sebaceous deserves full attention, with either close follow up, or excision with pathohistological analysis.
\end{abstract}

Key words: Nevus, Sebaceous of Jadassohn; Poroma; Neoplasms, Second Primary; Dermoscopy; Diagnosis

\section{Introduction}

Nevus sebaceus (NS) is a rare congenital hamartoma, composed of epidermis, sebaceous glands, sweat glands and hair follicles. It was first described by the German dermatologist Josef Jadassohn in $1895(1,2)$. NS may be present at birth or immediately after birth in $0.3 \%$ of newborns (3). During the lifetime, most often after puberty, the development of secondary tumors in the area of NS is possible. Secondary lesions are most often benign in nature, while malignant lesions may occur significantly less frequently, almost always in the adult population $(2,4)$. Most common benign lesions are trichoblastoma, syringocystadenoma papilliferum, while the most common malignant lesion is basal cell carcinoma $(4,5)$. Very rarely, eccrine poroma (EP) can occur in NS and mimic other benign and malignant tumors (6). EP is a benign neoplasm arising from the sweat gland ducts. It was first described in 1956 by Goldman and co-workers. It is most often localized on the palms and soles, although it can also be present on other parts of the body where the eccrine sweat glands are found (7). It is rarely described in papers in collision with NS.

\section{Case Report}

A 21-year old female presented due to the appearance of a nodule in the area of a yel-

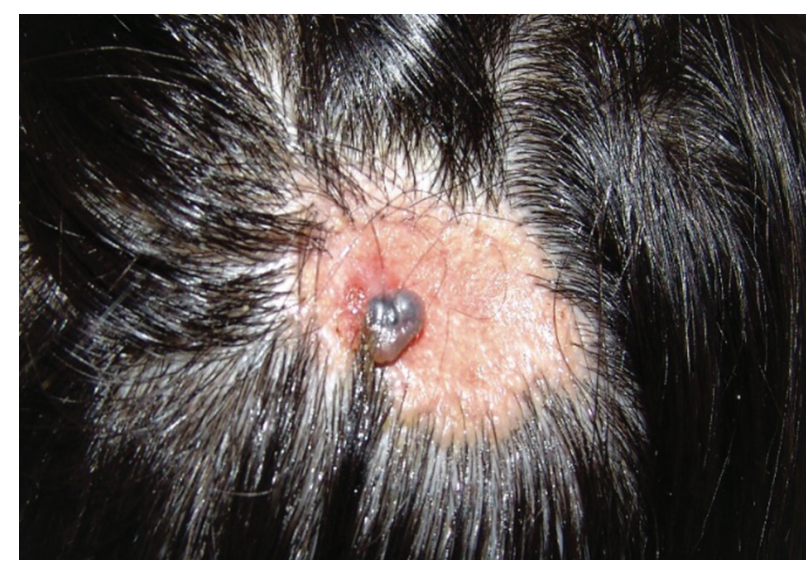

Figure 1. Yellowish slightly verrucous plaque with a reddish-bluish nodule in the area of the right parietal region 

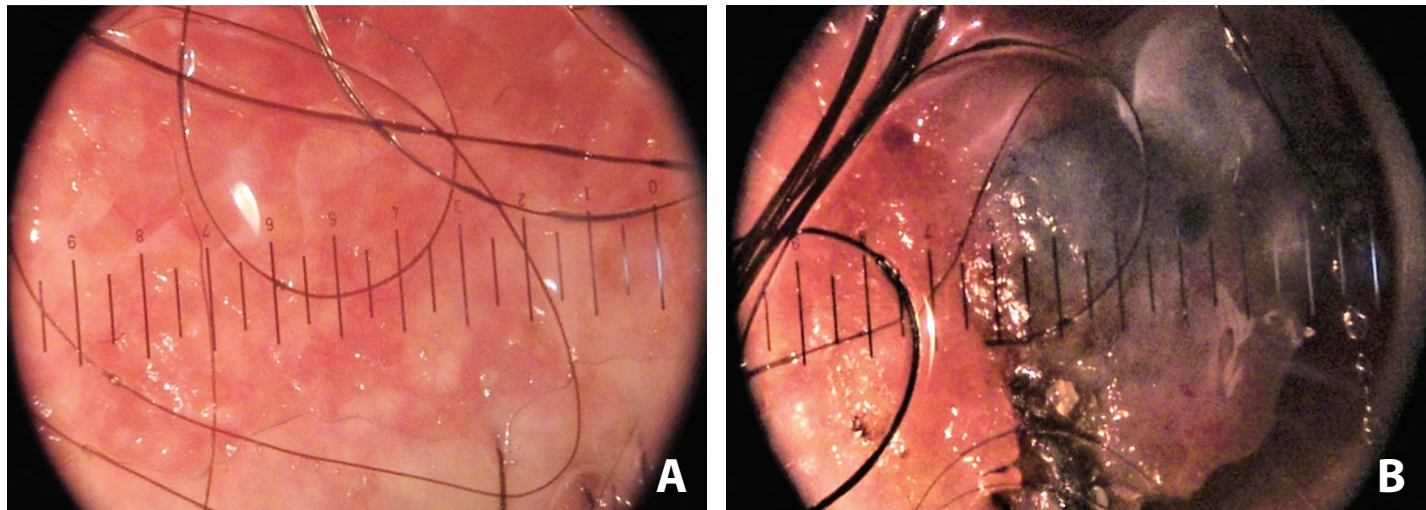

Figure 2. a. Dermoscopy of yellowish verrucous plaque: Yellow-whitish lobular appearance; b. Dermoscopy of reddish-bluish nodule: glomerular blood vessels, blue-black sign

lowish lesion on the head. The yellowish lesion was present since birth, and the nodule appeared about a year before. It was painless and the patient denied previous head injuries and other health problems. Clinical examination revealed a reddish-bluish nodule $1 \mathrm{~cm}$ in diameter on a yellowish slightly verrucous plaque, $3 \times 2 \mathrm{~cm}$ in diameter in the area of the right parietal region (Figure 1). On palpation, the nodule was of soft consistency. Regional lymph nodes were not enlarged. Dermoscopy of verrucous plaque showed a yellow-whitish lobular appearance (Figure 2a). This dermoscopic appearance was on the entire yellowish part without significant asymmetry. On the other hand, the pigmented nodule showed, although not characteristic, a blue-black sign which was present on the proximal two thirds and discrete glomerular blood vessels in the distal part (Figure 2b). Surgical excision of the plaque with a secondary lesion was performed. Pathohistological analysis of the excised lesion showed acanthotic epidermis with multiple, monomorphic cubic cells, which were smaller than keratinocytes, without peripherally formed palisades (Figure 3a). The hair follicle and hair shaft were surrounded with diffuse, dense chronic inflammatory infiltrate (Figure $\mathbf{3 b}$ ). In the tips of the papillae of the dermis there were hyperplastic sebaceous glands without hair follicles, with an opening directly into the epidermis (Figures 4 a and b). The marginal hair follicles and sebaceous glands were regular. The sweat glands were regularly located and of regular morphology. Based on the clinical and pathohistological findings, the final diagnosis of eccrine poroma arising within nevus sebaceous was made.
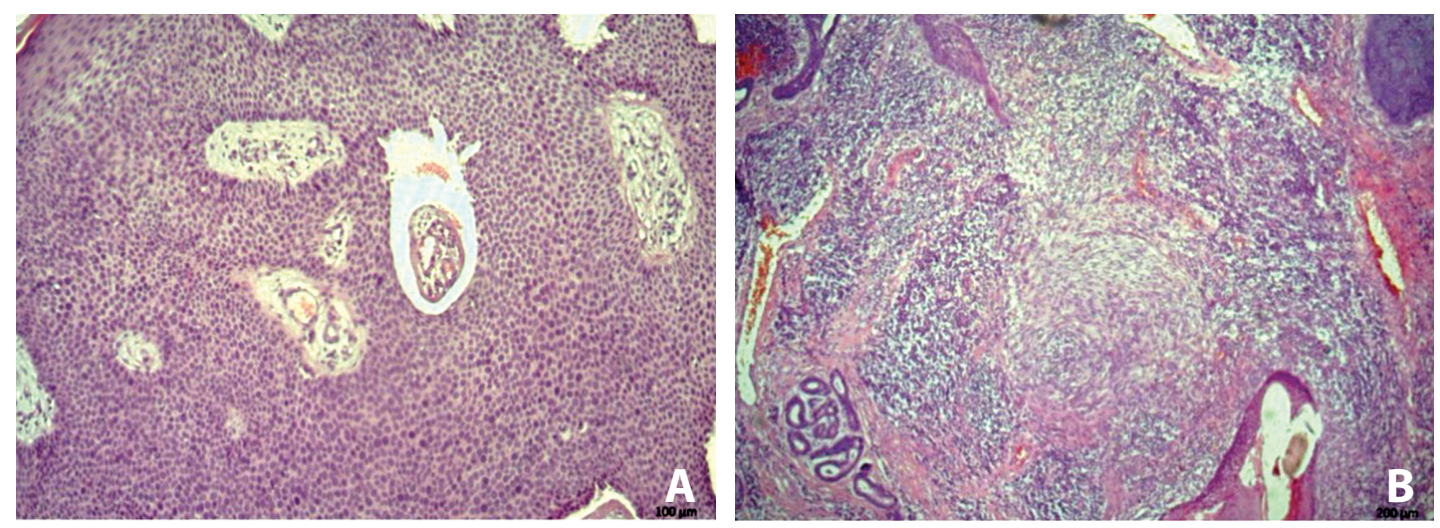

Figure 3. a. Ecrine poroma with acanthotic epidermis with multiple, monomorphic cubic cells, which are smaller than keratinocytes, without peripherally formed palisades (hematoxylin and eosin, x100); b. Part of a hair follicle with part of a hair shaft surrounded by a diffuse, dense chronic inflammatory infiltrate (hematoxylin and eosin, x50). 

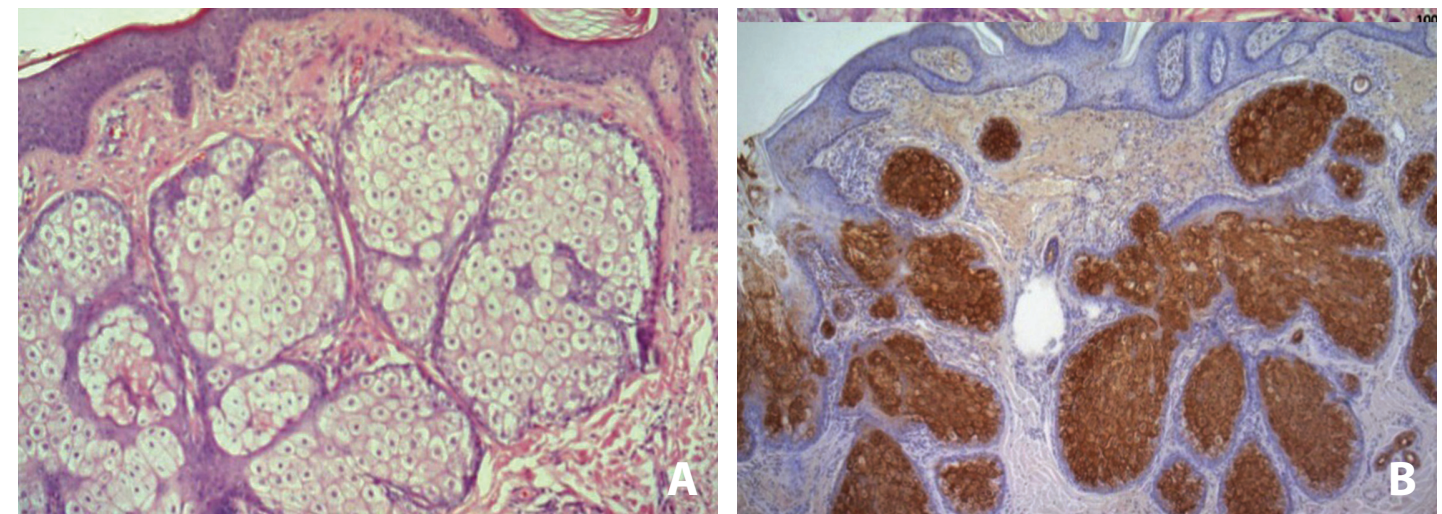

Figure 4. a. Hyperplastic sebaceous gland lobules without hair follicles (hematoxylin and eosin, x100); b. Immunohistochemical staining of multiplied sebaceous lobules (EMAx50)

\section{Discussion}

NS is a rare congenital hamartoma, composed of the epidermis, sebaceous glands, sweat glands and hair follicles (2). During the lifetime, NS changes its appearance and goes through three stages of development. At birth, clinically it has the appearance of a linear, circular or oval plaque of pink-yellow color, without hair, most often localized in the region of the head and neck. Dermoscopic characteristics of this stage are yellowish globules aggregated in the clusters. In puberty, during the second stage, NS becomes verrucous and dermoscopically is characterized by yellowishwhite lobular or yellowish-gray papillary structures, brown globules on a yellow background, or as in the first stage yellowish globules aggregated in clusters. After puberty, in the third stage of NS development, it is possible to develop secondary keratnocyte and adnexal tumors in the NS. At this stage, it is dermoscopically characterized by a homogeneous yellowish-white pattern and blood vessels can be present as linear, irregular, or arborescent (2, $3,8)$. In the case of our patient dermoscopy of plaque showed a yellow-whitish lobular appearance, without visible blood vessels.

Secondary lesions that occur in NS are most often benign in nature, while malignant lesions can occur significantly less frequently, almost always in the adult population $(2,4)$. Histopathology of early lesions shows a transient enlargement of sebaceous glands, acanthosis and mild papillomatosis may be present in the epidermis. In puberty, the development of mature sebaceous glands occurs, which are often located abnormally high in the dermis. Hair follicles remain small and may even disappear completely. The epidermis is more papillomatosus and acanthotic, and the dermis is often thickened. A mild chronic inflammatory cell infiltrate of lymphocytes and plasma cells is often present (9).

A retrospective study conducted by Munir H. Idriss analyzed NS from 1999 to 2012. Of the 707 NS analyzed, secondary lesions were identified in 159 samples (22.5\%). Of these, $18.9 \%(n=132)$ were benign lesions, while $2.5 \%(n=18)$ lesions were malignant, and $1.2 \%(n=9)$ contained warts, cysts, and connective tissue nevi. Among secondary benign lesions, the most common were trichoblastoma and syringocystadenoma papilliferum. The most common malignant secondary lesion was basal cell carcinoma (5). In our patient's case the pathohistological analysis showed benign neplasm arising in NS.

Diagnosis of NS can be straightforward based on history, clinical examination and dermoscopic picture $(2,3,8)$. It usually does not need to be excised, especially in children. However, there is still no consensus on whether and when the treatment is needed. Some authors point out that surgical excision is unnecessary for prophylactic reasons since secondary lesions on the NS do not occur often. They also state that most secondary lesions are benign in nature. However, other authors suggest that prophylactic excision before puberty is a better therapeutic modality than the long-term follow-up. They believe that secondary tumors occur more often after puberty when the NS is significantly larger and require more surgical intervention than in childhood when a NS is smaller $(2,5)$. 
We prefer clinico-dermoscopic approach as a solution for NS and NS with a secondary tumor.

Compliance with parents is essential in childhood. It is crucial to explain them the behavior of NS in childhood, and potential secondary tumors, most of them being of benign nature, and role of dermoscopy in doubtful situations $(5,8)$. If a secondary tumor is arising, it is usually benign. Dermoscopy can aid the diagnosis.

In a specific situation like NS and EP, although dermoscopic picture of NS is rather defined on one side, dermoscopic and clinical features of EP can be confusing on the other side. Clinical EP may have the appearance of a papule, verrucous plaque or exophytic skincolored nodule, somewhat less often the lesion may be pigmented. It is most often localized on the palms and soles (10). The differential diagnosis of EP is very broad. Dermoscopy can be very helpful so that we can differentiate them from other tumors: melanoma, pigmentary basal cell carcinoma, seborrheic keratosis, pyogenic granuloma, dermatofibroma, squamous cell carcinoma, Bowen disease, dermal nevus and angioma $(11,12)$. In a study conducted by the International Dermoscopy Society dermoscopic characteristics of EP include white interlacing areas around vessels, yellow structureless areas, milky-red globules and branched vessels with rounded endings (11). Pathohistological analysis of EP shows a circumscribed tumor composed of cords and columns of uniform basaloid cells. The cells are smaller than epidermal cells. Melanin pigment may be present. Ducts and small cysts may also be seen within the tumor columns (9).

In our patient's case, pigmentary basal cell carcinoma and melanoma in NS was considered as a differential diagnosis on the basis of clinical and dermoscopic findings. Dermoscopic examination of the lesion was very nonspecific, even bizarre in appearance. As such, it was highly suspicious, and malignancy could not be ruled out without pathohistology. The final diagnosis of EP as a secondary lesion in NS was made by pathohistological analysis.

\section{Conclusion}

Every secondary tumor in NS deserves full attention, with either close follow up, or excision with pathohistological analysis.

\section{Abbreviations \\ NS - Nevus sebaceus \\ EP - Eccrine poroma}

\section{References}

1. Weyers W. Josef Jadassohn - an appreciation on the occasion of his 150th birthday. Am J Dermatopathol. 2013;35(7):742-51.

2. Moody MN, Landau JM, Goldberg LH. Nevus sebaceous revisited. Pediatr Dermatol. 2012;29(1):15-23.

3. Alper J, Holmes LB, Mihm MC Jr. Birthmarks with serious medical significance: nevocullular nevi, sebaceous nevi, and multiple café au lait spots. J Pediatr. 1979;95(5 Pt 1):696-700.

4. Cribier B, Scrivener Y, Grosshans E. Tumors arising in nevus sebaceus: a study of 596 cases. J Am Acad Dermatol. 2000;42(2 Pt 1):263-8.

5. Idriss MH, Elston DM. Secondary neoplasms associated with nevus sebaceus of Jadassohn: a study of 707 cases. J Am Acad Dermatol. 2014;70(2):332-7.

6. Girdwichai N, Chanprapaph K, Vachiramon V. Eccrine poroma arising within nevus sebaceous. Case Rep Dermatol. 2016;8(1):80-4.

7. Kang MC, Kim SA, Lee KS, Cho JW. A case of an unusual eccrine poroma on the left forearm area. Ann Dermatol. 2011;23(2):250-3.

8. Kelati A, Baybay H, Gallouj S, Mernissi FZ. Dermoscopic analysis of nevus sebaceus of Jadassohn: a study of 13 cases. Skin Appendage Disord. 2017;3(2):83-91.

9. Patterson JW. Weedon's skin pathology. 4th ed. Philadelphia: Churchill Livingstone/Elsevier; 2016. Chapter 34, Tumors of cutaneous appendages; p. 951-1015.

10. Sawaya JL, Khachemoune A. Poroma: a review of eccrine, apocrine, and malignant forms. Int J Dermatol. 2014;53(9):1053-61.

11. Marchetti MA, Marino ML, Virmani P, Dusza SW, Marghoob AA, Nazzaro G, et al. Dermoscopic features and patterns of poromas: a multicentre observational case-control study conducted by the International Dermoscopy Society. J Eur Acad Dermatol Venereol. 2018;32(8):1263-71.

12. Lallas A, Chellini PR, Guimarães MG, Cordeiro N, Apalla Z, Longo C, et al. Eccrine poroma: the great dermoscopic imitator. J Eur Acad Dermatol Venereol. 2016;30(10):e61-3. 


\section{Pojava sekundarnog tumora u nevusu sebaceusu}

\section{Sažetak}

Uvod. Nevus sebaceus je redak kongenitalni hamartom, izgrađen od epiderma, sebacealnih žlezda, znojnih žlezda i folikula dlake. Tokom života, najčešće nakon puberteta, moguć je nastanak sekundarnih tumora u predelu nevusa sebaceus. Sekundarne lezije su najčešće benigne prirode, dok se značajno ređe mogu javiti i maligne lezije. Prikaz slučaja. Prikazujemo slučaj pacijentkinje starosti 21 godinu, koja je došla na pregled zbog pojave čvorića u predelu žućkaste lezije na pogla-

vini. Žućkasta lezija je bila prisutna od rođenja, dok se čvorić pojavio pre godinu dana. Dermoskopskim pregedom lezija je bila veoma nespecifična. Konačna dijagnoza ekrinog poroma kao sekundarne lezije u nevusu sebaceus postavljena je patohistološkom analizom. Zaključak. Svaki sekundarni tumor u nevusu sebaceus zaslužuje pažnju, kratkoročno praćenje ili eksciziju sa patohistološkom analizom.

Ključne reči: Nevus lojnih žlezda Jadasona; Porom; Druga primarna neoplazma; Dermoskopija; Dijagnoza

Received 20.12.2020.

Accepted 22.12.2020. 